\title{
THE INFLUENCE OF ULTRAVIOLET RADIATION ON THE COLOUR OF THERMO-MECHANICALLY MODIFIED BEECH AND OAK WOOD
}

\author{
Agnieszka Laskowska,
}

\begin{abstract}
The study examined the influence of ultraviolet radiation on the colour of thermo-mechanically modified beech (Fagus sylvatica) and oak (Quercus robur). The wood colour parameters were measured using the mathematical CIE L*a*b* and $\mathrm{L} * \mathrm{C} * \mathrm{~h}$ colour space models. The higher the temperature of thermo-mechanical treatment, the least susceptible beech and oak wood was to a change in $\mathrm{L}^{*}, \mathrm{a}^{*}$ and $\mathrm{b}^{*}$ under the influence of light irradiation. The greatest changes in the colour of non-densified and densified beech and oak wood occurred after $20 \mathrm{~h}$ of light irradiation. The higher the temperature of thermo-mechanical treatment, the smaller were the total changes in the colour of beech and oak wood under the influence of ultraviolet radiation. The total changes in the colour of beech densified at temperatures of $100^{\circ} \mathrm{C}$ and $150^{\circ} \mathrm{C}$ that took place under the influence of ultraviolet radiation were twice as high as in the case of densified oak wood. The colour of oak wood modified at a temperature of $200^{\circ} \mathrm{C}$ did not change significantly in $300 \mathrm{~h}$ of light irradiation.
\end{abstract}

Keywords: Chromatic coordinates, densification, Fagus sylvatica, Quercus robur, wood modification.

\section{INTRODUCTION}

Wood as an organic material has a number of characteristics which make its use difficult, such as: anisotropic structure, hygroscopicity, dimensional changes depending on the parameters of the air, or susceptibility to biological corrosion. A number of wood species have low density, which additionally limits their use. This defect can be compensated by the modification of wood using thermo-mechanical treatment, which is reflected in numerous studies concerning the densification of wood with a density below $500 \mathrm{~kg} / \mathrm{m}^{3}$ (Tu et al. 2014, Pelit et al. 2016, Zhan and Avramidis 2016). Studies are also conducted with respect to the densification of wood coming from plantations of fast-growing trees (Rautkari et al. 2011, Kutnar and Kamke 2012, Xu and Tang 2012, Fang et al. 2019). High density species, such as European beech, are also modified using thermo-mechanical treatment (Blomberg et al. 2005, Rautkari et al. 2010). The essential purpose of modifying this type of wood is to obtain material characterised by greater hardness and, consequently, greater usefulness. One of the most important problems is the selection of appropriate pressing parameters for particular wood species, as they differ in terms of their chemical composition and anatomical structure. The technological process must be developed so as to ensure that the wood to be modified is not destroyed in the course of treatment, does not change significantly its original, aesthetic appearance and can be used as a high quality raw material (Laskowska and Sobczak 2018). Densification is one of the methods of wood modification, which makes it possible to give new utility characteristics to wood species with low quality and technical specifications. An effect of such processes is also the enhancement of the economic significance of wood species with low market competitiveness and, consequently, the furtherance of rational management of forest resources.

The process of thermo-mechanical modification of wood is usually conducted in a hydraulic press equipped with heated plates (Laine et al. 2013b, Bekhta et al. 2014a, Bekhta et al. 2014b, Laine et al. 2016, Laskowska 
et al. 2018). Occasionally, especially designed or modified machines are used, which enables the introduction of steam in the course of treatment (Kutnar et al. 2009, Fang et al. 2011, Pařil et al. 2014, Cruz et al. 2018, Fang et al. 2019). The technological process is often divided into several stages, including, in addition to the main pressing operation, also the preliminary and final treatment. This usually consists in exposing wood to water and/or temperature with diversified parameters. The purpose of these operations is the preliminary plastification of wood aimed at facilitating the process, or at reducing internal stresses after the treatment in order to prevent deformations (Rautkari et al. 2013, Popescu et al. 2014, Zhan and Avramidis 2016). Wood surface can also be densified using the linear vibration friction technology (Rautkari et al. 2009).

There are a number of studies concerning the effect of technological factors on the anatomical structure (Kutnar et al. 2009, Rautkari et al. 2009, Dogu et al. 2010, Ahmed et al. 2013, Laine et al. 2014) and physical and mechanical properties of densified wood (Ulker et al. 2012, Belt et al. 2013, Laine et al. 2013a, Bekhta et al. 2014a, Bekhta et al. 2014b, Bekhta and Krystofiak 2016, Rautkari et al. 2013, İmirzi et al. 2014, Gašparik et al. 2016, Zhan and Avramidis 2016). The effect of post-treatment parameters is also analysed, in particular, on the hygroscopic properties of densified wood (Welzbacher et al. 2008, Kutnar and Kamke 2012, Pelit et al. 2014, Laine et al. 2013b, Laine et al. 2016). Thermo-mechanical modification significantly influences the colour of wood, offering a possibility of making wood species similar, in terms of colour, to exotic wood. Bekhta et al. (2014a), Bekhta et al. 2014b examined the effect of short-term thermo-mechanical (STTM) densification temperature and pressure on the surface colour and gloss of alder, beech, birch and pine wood veneers. It should be noted that especially the effect of thermal treatment on the colour of wood is analysed in literature (Ayadi et al. 2003, Brischke et al. 2007, González-Peña and Hale 2009, Tolvaj et al. 2014), while there is no comprehensive data on the influence of abiotic factors, i.e. ultraviolet radiation, on the colour of densified wood. The issue is even more important, because the colour stability is one of the primary factors determining the usefulness of wood. This refers mainly to wood used as flooring materials, veneers or materials for the production of furniture. Furthermore, the colour change of wood is the most sensitive indicator for the degradation caused by sunlight (Tolvaj and Mitsui 2010). The colour of wood indirectly also constitutes an indicator of the quality and strength of wood (Bekhta and Niemz 2003, Johansson and Morén 2006). Therefore, research concerning the influence of ultraviolet radiation on the properties of densified wood is justified.

The purpose of the study was to determine the influence of ultraviolet radiation on the colour of thermo-mechanically modified beech (Fagus sylvatica) and oak (Quercus robur) wood. A particularly important aspect was to define the change in the parameters of the wood colour in time. Also, the significance and the extent of the influence of material-related (wood species) and technological (densification temperature) factors on the change in the parameters of the colour of wood in time were analysed.

\section{MATERIALS AND METHODS}

\section{Materials}

Beech (Fagus sylvatica L.) wood and oak (Quercus robur L.) heartwood from the forest in the central Poland, managed by The State Forests National Forest Holding, was used for the study. The surface of the samples was finished by planing. Samples without visible defects were selected. Samples with the dimensions of $120 \mathrm{~mm}$ (longitudinal), $60 \mathrm{~mm}$ (radial) x $5 \mathrm{~mm}$ (tangential) were used for the study. 30 samples were used for each variant of thermo-mechanical modification. The samples were conditioned for three months in a normal climate (temperature $20^{\circ} \mathrm{C} \pm 2{ }^{\circ} \mathrm{C}$, relative humidity $65 \% \pm 5 \%$ ). Subsequently, 20 samples were selected randomly out of 30 samples, and were exposed to light irradiation.

\section{Thermo-mechanical modification of wood}

The modification process was conducted in a single plate hydraulic press. The temperature of the press plates was $100^{\circ} \mathrm{C}, 150^{\circ} \mathrm{C}$ and $200^{\circ} \mathrm{C}$, the unit pressure was $80 \mathrm{MPa}$. The treatment comprised three stages: (1) heating the wood samples for $180 \mathrm{~s}$ with the closed press plates without exerting pressure, (2) pressing at the assumed pressure for $180 \mathrm{~s}$, (3) cooling the wood samples in an unheated hydraulic press without exerting pressure. The cooling process was carried out until the wood achieved the temperature of $70^{\circ} \mathrm{C}$. 


\section{Ultraviolet radiation}

Four fluorescent lamps were used for ultraviolet radiation, each with a capacity of 100W (model 100R, LIGHTECH company, Poland). Wood samples were subjected to ultraviolet radiation within a spectrum range of $300-400 \mathrm{~nm}$. Tolvaj and Mitsui (2010) used a xenon lamp at $180 \mathrm{~W} / \mathrm{m}^{2}$, ranging from $300 \mathrm{~nm}$ to $400 \mathrm{~nm}$, and a strong UV light emitter, i.e. a mercury vapour lamp with total light emission of $320 \mathrm{~W}$, for wood light irradiation. The source of radiation applied in this study imitated solar radiation, and in particular the UVA component of solar radiation. This component causes the greatest changes in the appearance and structure of organic materials exposed in an outdoor environment. This is due to the fact that UVA radiation accounts for $90-95 \%$ of the solar radiation reaching the Earth surface (Miller et al. 1998). Colour parameters were measured at two points of the sample, which in aggregate enabled the results to be collected from 40 measurement points for each of the modification variant. The wood samples were light irradiated for $300 \mathrm{~h}$, with the colour parameters being determined after each consecutive $20 \mathrm{~h}$ of irradiation.

\section{Properties measurement}

The wood moisture content was determined in accordance with the ISO 13061-1 (2014) requirements, and the density in accordance with ISO 13061-2 (2014). The wood moisture content was $6,36 \%( \pm 0,26 \%)$. The compression ratio (CR) was calculated according to Equation 1, where $t_{o}$ is the original thickness $(\mathrm{mm})$, and $\mathrm{t}_{\mathrm{d}}$ is the thickness of wood after densification $(\mathrm{mm})$.

$$
C R=\left[\left(t_{o}-t_{d}\right) / t_{o}\right] \times 100(\%)
$$

The parameters of the colour of unmodified and modified wood were measured on the basis of the mathematical CIE $\mathrm{L}^{*} \mathrm{a}^{*} \mathrm{~b}^{*}$ and $\mathrm{L}^{*} \mathrm{C}^{*} \mathrm{~h}$ colour space models. The lightness $\left(\mathrm{L}^{*}\right)$, chromatic coordinate on the redgreen axis $\left(\mathrm{a}^{*}\right)$ and chromatic coordinate on the yellow-blue axis $\left(\mathrm{b}^{*}\right)$ before and after densification and radiation were determined. The parameters $\mathrm{C}^{*}$ and $\mathrm{h}$ describe the saturation (colour intensity) and hue angle, respectively. The total colour change $\Delta \mathrm{E}$ was determined in accordance with ISO 7724-3 (1984). The SP60 spectrophotometer made by X-Rite Europe GmbH (Regensdorf, Switzerland) was used to examine the colour parameters. The sensor head was $8 \mathrm{~mm}$ in diameter. Measurements were made using a D65 illuminant.

\section{Statistical analysis}

The statistical analysis of the results was performed using the STATISTICA Version-12 software of StatSoft, Inc. (Tulsa, USA). The significance of the influence of the wood species and the temperature of thermo-mechanical treatment on the degree of wood compression (CR), density, colour parameters ( $\mathrm{L}^{*}, \mathrm{a}^{*}, \mathrm{~b}^{*}$, $\left.\mathrm{C}^{*}, \mathrm{~h}\right)$ and the change in colour $(\Delta \mathrm{E})$ was determined. It was specified to what extent the wood species and the temperature of treatment affected the wood colour parameters immediately after the modification (parameters with the symbol M, e.g. L*_M) and after $300 \mathrm{~h}$ of light irradiation of the wood (parameters with the symbol R, e.g. $L^{*}$ R). Also the influence of the wood species and the temperature of treatment on the colour change $\Delta \mathrm{E}$ after $20 \mathrm{~h}$ and $300 \mathrm{~h}$ of light irradiation was analysed (marked, respectively as $\Delta \mathrm{E} \_20 \mathrm{R}$ and $\Delta \mathrm{E} \_300 \mathrm{R}$ ). The statistical analysis of the results was performed at a significance level of 0,05 . In the case of analysed parameters of wood colour the trend lines were determined and the parameters of the equation of curve (y) as well as the coefficient of determination $\mathrm{R}^{2}$ were provided.

\section{RESULTS AND DISCUSSION}

The statistical evaluation of the influence of factors (based on ANOVA, Fischer's F-test) on the parameters of densified wood was shown in Table 1 . The wood species demonstrated a significant influence only on the values of $\mathrm{L}^{*}$ and $\mathrm{a}^{*}$ of the wood after modification. Whereas after $300 \mathrm{~h}$ of light irradiation, the wood species demonstrated an influence on all the colour parameters and $\Delta \mathrm{E}(\mathrm{p}<0,05)$. The temperature of thermo-mechanical treatment had a significant influence on $\mathrm{CR}$, density, and all the colour parameters determined immediately after the modification of the wood and after $300 \mathrm{~h}$ of light irradiation. The temperature of treatment 
demonstrated also a significant influence on the total colour change $\Delta \mathrm{E}$ after $20 \mathrm{~h}$ and $300 \mathrm{~h}$ of light irradiation $(p<0,05)$. It should be noted that the interaction between the wood species and the temperature of treatment showed a significant influence on all the wood properties under study, in particular on $b^{*}, C^{*}, h$ (influence at the level of 30-40\%). When analysing the percentage impact of factors on the properties of the densified beech and oak wood, it is worth noting that there were considerable differences in the influence of these factors. The temperature of treatment influenced the parameters of the modified wood to a greater extent than the wood species. It should be noted that the temperature of treatment showed the greatest influence on CR and the density of wood ( $98 \%$ and $94 \%$ respectively). In the case of colour parameters, the temperature of treatment showed the greatest influence on $\mathrm{L}^{*}$ and $\mathrm{h}$ (influence at the level of 54-60\%), and the least significant on $\mathrm{a}^{*}(15-31 \%)$. Significant differences in $\mathrm{b}^{*}, \mathrm{C}^{*}, \mathrm{~h}$, and also $\Delta \mathrm{E}$, depending on the species of the wood, were found after 300 $\mathrm{h}$ of light irradiation, with no such correlation being found after the wood was modified. The temperature of modification and the interaction between the wood species and the temperature of treatment were more significant. This shows that the susceptibility of beech and oak wood to photodegradation is different.

Table 1: Statistical evaluation of the factors influencing the parameters of thermo-mechanically densified wood.

\begin{tabular}{|c|c|c|c|c|c|c|}
\hline \multirow{4}{*}{ Factor } & \multicolumn{6}{|c|}{ Properties } \\
\hline & \multicolumn{3}{|c|}{ Compression ratio } & \multicolumn{3}{|c|}{ Density } \\
\hline & $\begin{array}{l}\text { Fisher's } \\
\text { F-test }\end{array}$ & $\begin{array}{c}\text { Significance } \\
\text { level }\end{array}$ & $\begin{array}{c}\text { Factor } \\
\text { Influence } \\
(\%)\end{array}$ & $\begin{array}{l}\text { Fisher's } \\
\text { F-test }\end{array}$ & $\begin{array}{c}\text { Significance } \\
\text { level }\end{array}$ & $\begin{array}{c}\text { Factor } \\
\text { Influence } \\
(\%)\end{array}$ \\
\hline & $\mathbf{F}$ & $\mathbf{p}$ & $\mathbf{x}$ & $\mathbf{F}$ & $\mathbf{p}$ & $\mathbf{x}$ \\
\hline Species(1) & 2,69 & 0,106858 & 0 & 0,42 & 0.519629 & o \\
\hline Temp.(2) & 1618,21 & 0,000000 & 98 & 503,60 & 0,000000 & 94 \\
\hline$(1) \times(2)$ & 10,22 & 0,000018 & 1 & 13,80 & 0,000001 & 3 \\
\hline \multirow[t]{3}{*}{ Error } & \multirow{2}{*}{\multicolumn{3}{|c|}{$\mathrm{L}^{*} \mathrm{M}$}} & \multicolumn{2}{|l|}{+2} & 3 \\
\hline & & & & L* R & & \\
\hline & $\bar{F}$ & $\mathrm{p}$ & $\mathrm{x}$ & $\bar{F}$ & p & $\mathrm{x}$ \\
\hline (1) & 564,62 & 0,000000 & 28 & 590,67 & 0,000000 & 31 \\
\hline (2) & 408,93 & 0,000000 & 60 & 347.20 & 0,000000 & 55 \\
\hline$(1) \times(2)$ & 58,51 & 0,000000 & 9 & 66,88 & 0,000000 & 11 \\
\hline \multirow[t]{3}{*}{ Error } & \multirow{2}{*}{\multicolumn{3}{|c|}{ a*_M }} & & & 3 \\
\hline & & & & \multicolumn{3}{|l|}{$a^{*} \mathrm{R}$} \\
\hline & $\overline{\mathrm{F}}$ & $\mathrm{p}$ & $\mathrm{x}$ & $\bar{F}$ & $\mathrm{p}$ & $\mathrm{x}$ \\
\hline (1) & 50,70 & 0,000000 & 18 & 68,93 & 0,000000 & 32 \\
\hline (2) & 29,32 & 0,000000 & 31 & 11,12 & 0,000004 & 15 \\
\hline$(1) \times(2)$ & 22,87 & 0,000000 & 25 & 14,04 & 0,000000 & 19 \\
\hline \multirow[t]{3}{*}{ Error } & & & 26 & & & 34 \\
\hline & \multicolumn{3}{|l|}{$b^{*}=M$} & \multicolumn{3}{|l|}{$b^{*} \quad \mathrm{R}$} \\
\hline & $\overline{\mathbf{F}}$ & $\mathrm{p}$ & $\mathrm{x}$ & $\bar{F}$ & p & $\mathrm{x}$ \\
\hline (1) & 0,77 & 0,382196 & $\mathrm{O}$ & 119,17 & 0,000000 & 15 \\
\hline (2) & 66,35 & 0,000000 & 43 & 133,39 & 0,000000 & 49 \\
\hline (1) $\times(2)$ & 64,99 & 0,000000 & 42 & 72,90 & 0,000000 & 27 \\
\hline \multirow[t]{3}{*}{ Error } & \multicolumn{2}{|l|}{$2 \mathrm{~F} 20 \mathrm{~B}$} & 15 & \multicolumn{2}{|l|}{$\mathrm{AE} 300 \mathrm{R}$} & 9 \\
\hline & $\Delta \mathrm{E}_{2} 2 \mathrm{OR}$ & & & $\triangle \mathrm{E} \_300 \mathrm{R}$ & & \\
\hline & & $p$ & $x$ & & $\mathrm{p}$ & $\mathrm{x}$ \\
\hline (1) & 1,716 & 0,194379 & 0 & 438,964 & 0,000000 & 40 \\
\hline (2) & 45,479 & 0,000000 & 39 & 171,457 & 0,000000 & 47 \\
\hline$(1) \times(2)$ & 45,146 & 0,000000 & 39 & 19,752 & 0,000000 & 5 \\
\hline \multirow[t]{3}{*}{ Error } & \multirow{2}{*}{\multicolumn{2}{|c|}{$\mathrm{C}^{*} \mathrm{M}$}} & 22 & \multirow{2}{*}{\multicolumn{2}{|c|}{$C^{*}$ R }} & 8 \\
\hline & & & & & & \\
\hline & $\overline{\mathrm{F}}$ & $\mathrm{p}$ & $\mathrm{x}$ & $\bar{F}$ & p & $\mathrm{x}$ \\
\hline (1) & 2,11 & 0,150861 & 0 & 115,37 & 0,000000 & 16 \\
\hline (2) & 53,56 & 0,000000 & 38 & 109,80 & 0,000000 & 47 \\
\hline (1) $\times(2)$ & 62,93 & 0,000000 & 45 & 63,54 & 0,000000 & 27 \\
\hline \multirow[t]{3}{*}{ Error } & \multirow{2}{*}{\multicolumn{2}{|c|}{ h M }} & 17 & & & 10 \\
\hline & \multirow{2}{*}{\multicolumn{2}{|c|}{$\mathrm{F}$}} & & \multicolumn{2}{|l|}{ h_R } & \\
\hline & & & $\mathrm{x}$ & \multicolumn{2}{|l|}{$\bar{F}$} & $\mathrm{x}$ \\
\hline (1) & 0,01 & 0,902933 & 0 & 36,61 & 0,000000 & 6 \\
\hline (2) & 83,71 & 0,000000 & 60 & 114,36 & 0,000000 & 54 \\
\hline$(1) \times(2)$ & 32,87 & 0,000000 & 23 & 60,52 & 0,000000 & 29 \\
\hline Error & & & 17 & & & 11 \\
\hline
\end{tabular}

Depending on the species and the temperature of modification, CR ranged from $37 \%( \pm 2 \%)$ to $44 \%( \pm 1 \%)$. The beech wood was compressed to a lesser extent at temperatures of $100^{\circ} \mathrm{C}$ and $150^{\circ} \mathrm{C}$ than the oak wood (Figure 1a). The differences were due to the anatomical structure of the wood. The earlywood in the oak wood was compressed to a greater extent than the "homogeneous" structure of the beech wood. The differences in densification of the wood were levelled at a temperature of $200^{\circ} \mathrm{C}$. The absence of morphology differences between earlywood and latewood in hybrid poplar after the viscoelastic thermal compression was noted by Kutnar et al. (2009). Ahmed et al. (2013) noted uniform densification of the zones of diffuse-porous aspen and birch wood. Differences in densification of earlywood and latewood of pine were demonstrated by Dogu et al. (2010) and Laine et al. (2016). Schrepfer and Schweingruber (1998), Navi and Girardet (2000) recorded differences between the earlywood and latewood structure in densified spruce wood. 

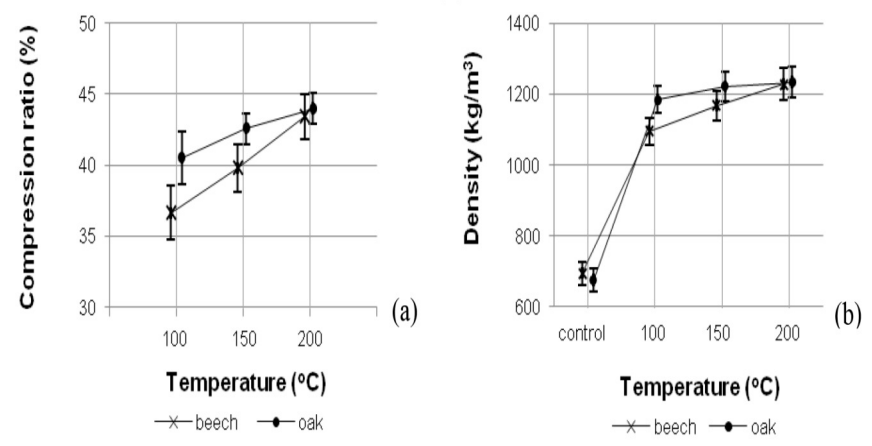

Figure 1: Compression ratio (a) and density (b) of densified beech and oak wood.

The density of non-densified beech wood was $695 \mathrm{~kg} / \mathrm{m}^{3}\left( \pm 32 \mathrm{~kg} / \mathrm{m}^{3}\right)$, whereas in the case of oak wood it was $675 \mathrm{~kg} / \mathrm{m}^{3}\left( \pm 42 \mathrm{~kg} / \mathrm{m}^{3}\right)$. This value was comparable to values cited in previous literature. According to Wagenführ (2007), beech wood (Fagus sylvatica) density in an air-dry condition ranges from $540 \mathrm{~kg} / \mathrm{m}^{3}$ to $910 \mathrm{~kg} /$ $\mathrm{m}^{3}$, with the mean value $720 \mathrm{~kg} / \mathrm{m}^{3}$. Whereas oak wood (Quercus robur) density in an air-dry condition ranges from $430 \mathrm{~kg} / \mathrm{m}^{3}$ to $960 \mathrm{~kg} / \mathrm{m}^{3}$, with the mean value $690 \mathrm{~kg} / \mathrm{m}^{3}$. The density of beech and oak increased as higher temperatures of treatment were applied (Figure 1b). The density of beech wood densified at temperatures of $100^{\circ} \mathrm{C}, 150^{\circ} \mathrm{C}$ and $200^{\circ} \mathrm{C}$ was, respectively $60 \%, 70 \%$ and $80 \%$ higher than the density of non-densified beech wood. Whereas the density of densified oak wood was $80 \%$ higher than the density of oak wood before modification, irrespective of the temperature of densification. This correlation may be caused by the greater softening of wood at a higher temperature (Salmén 1982, Fang et al. 2011, Tu et al. 2014). Alén et al. (2002) noted that upon the temperature exceeding $100^{\circ} \mathrm{C}$, the intermolecular and intramolecular chemical bonds begin to break. Whereas Jiang et al. (2009) noted that upon the temperature reaching $160^{\circ} \mathrm{C}$, lignin molecules separate from one another, their positions change and the adhesive linkage of lignin with cellulose fibrils is destroyed.

The lightness $\left(\mathrm{L}^{*}\right)$ of unmodified beech and oak wood was respectively $72,42( \pm 1,32)$ and $66,76( \pm 1,31)$. The higher the temperature of thermo-mechanical modification, the more intense was the darkening of wood. The modification of beech wood at temperatures of $100^{\circ} \mathrm{C}$ and $150^{\circ} \mathrm{C}$ caused slight changes (a decrease in the value of $\mathrm{L}^{*}$ by ca. $4 \%$ ), with the differences being statistically significant $(\mathrm{p}<0,05)$. Only treatment at a temperature of $200^{\circ} \mathrm{C}$ resulted in a clear colour change (decrease in the value of $\mathrm{L}^{*}$ by ca. $19 \%$ ). Bekhta et al. (2014a) found a similar correlation during examination the effect of short-term thermo-mechanical (STTM) densification temperature and pressure on the surface colour of veneer of alder, beech, birch and pine. The modification of oak wood resulted in a noticeable change in the darkening of wood, already at a temperature of $100^{\circ} \mathrm{C}$ (decrease in the value of $\mathrm{L}^{*}$ by ca. $9 \%$ ). The oak wood was less resistant to a temperature of $200^{\circ} \mathrm{C}$ than beech wood. The $\mathrm{L}^{*}$ value for the oak wood densified at a temperature of $200^{\circ} \mathrm{C}$ was $45 \%$ lower than the $\mathrm{L}^{*}$ value for non-densified oak wood. According to Diouf et al. (2011) and Bekhta et al. (2014a), a decrease in the lightness of wood as a result of treatment may be caused by the degradation of hemicelluloses. Hemicelluloses degrade more easily under the influence of an increased temperature, as a result of which the lignin content in wood increases (Laskowska et al. 2018). An effect of that was the darkening of wood. Hemicelluloses degrade and the lignin content in wood increases as the temperature of modification rises. Such changes are especially visible in hardwood, which has a higher hemicelluloses content than softwood wood. Furthermore, the higher the temperature of heat treatment, the greater the degradation of hemicelluloses (Huang et al. 2012, Esteves et al. 2013, Pétrissans et al. 2014). 

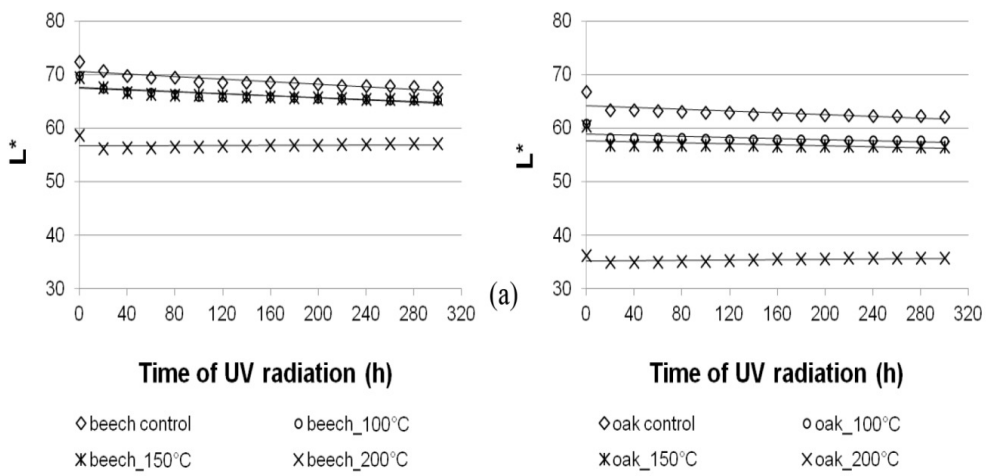

$\begin{array}{lr}\text { Time of UV radiation (h) } \\ \text { ooak control } \\ \text { *oak_ } 150^{\circ} \mathrm{C} & \text { ooak_ } 100^{\circ} \mathrm{C} \\ & \text { xoak_ } 200^{\circ} \mathrm{C}\end{array}$

Figure 2: Change of lightness $\left(\mathrm{L}^{*}\right)$ of beech (a) and oak (b) wood under UV radiation exposure.

Light irradiation had the greatest effect on the change in the lightness of unmodified wood, and the smallest effect on the lightness of wood densified at a temperature of $200^{\circ} \mathrm{C}$. This correlation concerned both beech and oak wood. The lightness of non-densified wood, modified at temperatures of $100^{\circ} \mathrm{C}$ and $150^{\circ} \mathrm{C}$ after $300 \mathrm{~h}$ of light irradiation, was ca. 7\% lower than the lightness of wood before light irradiation and the differences were statistically significant $(\mathrm{p}<0,05)$. Whereas the lightness of wood modified at a temperature of $200^{\circ} \mathrm{C}$ after 300 $\mathrm{h}$ of light irradiation did not change significantly. These correlations were an effect of transformations of wood components in the course of thermo-mechanical treatment. Beech and oak wood modified at a higher temperature had a darker colour and, consequently, was less susceptible to a change in colour under the influence of light irradiation.

The study showed that the most substantial changes in wood lightness occurred after $20 \mathrm{~h}$ of UV radiation exposure (Figure 2). After that time, the $\mathrm{L}^{*}$ value change was linear. Tolvaj and Mitsui (2010) examining unmodified black locust, beech, Japanese cedar and spruce wood stated that the greatest changes in the lightness of wood occurred during the first $20 \mathrm{~h}$ of light irradiation by sun and xenon lamp. Similar correlations were found in the studies conducted by Pastore et al. (2004) and Pandey (2005b). The oak wood, both non-densified and densified (irrespective of the temperature of modification) showed a greater susceptibility to a change in the value of L* after $20 \mathrm{~h}$ of light irradiation than beech wood. Changes in lightness occurring in $20 \mathrm{~h}$ accounted for about $85 \%$ of the total change in the oak and about $40 \%$ in the beech wood. An exception was beech and oak wood densified at a temperature of $200^{\circ} \mathrm{C}$. Changes in the lightness occurring in $20 \mathrm{~h}$ were 1,5 and 2,5 times greater than the total changes in the lightness of appropriately densified beech and oak wood. After $300 \mathrm{~h}$ of light irradiation, the $\mathrm{L}^{*}$ value for non-densified beech wood was $10 \%$ higher than the $\mathrm{L}^{*}$ value for non-densified oak wood and the differences were statistically significant $(p<0,05)$. Whereas the $L^{*}$ value for beech wood densified at a temperature of $200^{\circ} \mathrm{C}$ was $60 \%$ higher than the $\mathrm{L}^{*}$ value for oak wood densified at a temperature of $200^{\circ} \mathrm{C}$.
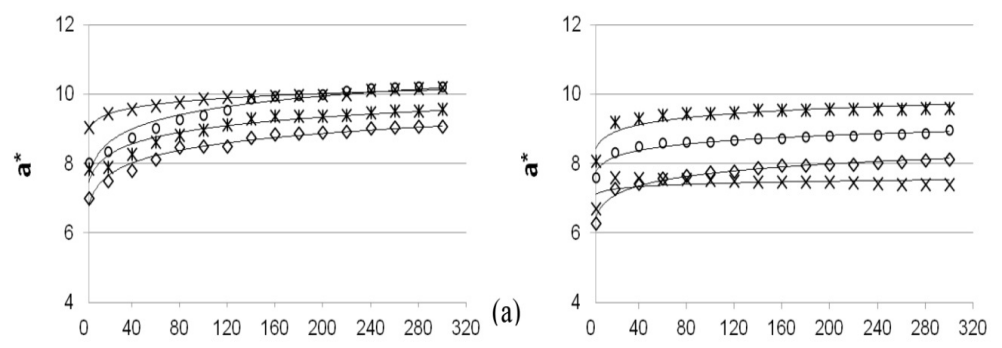

(b)

Time of UV radiation $(\mathbf{h})$
obeech control
*beech_150 $150^{\circ} \mathrm{C}$
obeech_100 $100^{\circ} \mathrm{C}$
xbeech_ $200^{\circ} \mathrm{C}$

Time of UV radiation (h)
ooak control
*oak_150 $\quad$ ooak_ $100^{\circ} \mathrm{C}$

Figure 3: Change in $a^{*}$ parameter of beech (a) and oak (b) wood colour under UV radiation exposure. 
The value of the chromatic coordinate on the red-green colour axis $\left(\mathrm{a}^{*}\right)$ for unmodified beech and oak wood was respectively $6,99( \pm 0,36)$ and $6,26( \pm 0,26)$. The higher the temperature of treatment, the more intense was the change in colour towards red. An exception was oak wood densified at a temperature of $200^{\circ} \mathrm{C}$. An increase in the value of the $a^{*}$ parameter was at the level of $7 \%$ and the differences were not statistically significant $\mathrm{p}>0,05)$. The modification of beech wood at $100^{\circ} \mathrm{C}$ and $150^{\circ} \mathrm{C}$ resulted in an increase in the value of a* by ca. $15 \%$. Treatment at $200^{\circ} \mathrm{C}$ caused a $30 \%$ increase in the value of a* for beech wood. A similar change in the value of $\mathrm{a}^{*}$ was recorded for oak wood densified at temperatures of $100^{\circ} \mathrm{C}$ and $150^{\circ} \mathrm{C}$, with these differences being statistically significant $(\mathrm{p}<0,05)$. A change in colour towards red is due to the presence of extractives in the wood (Yazaki et al. 1994, Gierlinger et al. 2004, Bekhta et al. 2014a).

Wood exposed to light irradiation showed another direction of change in the value of a*. Wood densified at a higher temperature was less susceptible to a change in the value of $a^{*}$ under the influence of light irradiation (Figure 3). These correlations are an effect of the transformation of extractives in the course of thermo-mechanical treatment. Hill (2006) notes that the production of condensable fractions occurs with loss of water and volatile extractives at temperatures below about $140^{\circ} \mathrm{C}$. The studies conducted show that the smaller the share of extractives in wood, the lower its susceptibility to a change in colour towards red. These correlations are confirmed by the studies conducted by Tolvaj et al. (2014), concerning the influence of ultraviolet radiation on the colour of thermally modified wood. The studies conducted by Mitsui et al. (2001) show that light irradiation resulted in a small redness increase in dry condition, but the wet thermal treatment created an eight times greater redness increase. The greatest change in the value of a* (30\% increase) was observed for non-densified beech and oak wood. After $300 \mathrm{~h}$ of light irradiation, the value of $\mathrm{a}^{*}$ for beech wood densified at temperatures of $100^{\circ} \mathrm{C}, 150^{\circ} \mathrm{C}$ and $200^{\circ} \mathrm{C}$ was, respectively, $27 \%, 22 \%$ and $13 \%$ higher than before light irradiation. The value of a* for oak wood densified at temperatures of $100^{\circ} \mathrm{C}, 150^{\circ} \mathrm{C}$ and $200^{\circ} \mathrm{C}$ was, respectively, $21 \%, 19 \%$ and $11 \%$ higher than before light irradiation. After light irradiation, smaller differences in the value of $\mathrm{a}^{*}$ could be observed in beech wood than in oak wood. Beech and oak wood showed tendency to become redder due to the reduction of a tonality component in colour and increasing colour saturation $C^{*}$ (Table 3 ), with the correlations between the values of $\mathrm{C}^{*}$ and $\mathrm{a}^{*}$ and the values of $\mathrm{h}$ and $\mathrm{a}^{*}$ being greater for the oak wood.

Changes in the chromatic coordinate value on the yellow-blue colour axis $\left(\mathrm{b}^{*}\right)$ were analysed and the results are presented in Figure 4. The value of $b^{*}$ for non-densified beech and oak wood was respectively 18,19 $( \pm 0,34)$ and $20,25( \pm 0,39)$. As a result of the thermo-mechanical modification of beech and oak wood, the value of $b^{*}$ increased by $3-9 \%$, with the differences being statistically significant $(p<0,05)$. An exception was oak wood densified at a temperature of $200^{\circ} \mathrm{C}$, for which the recorded value of $b^{*}$ was twice as low as compared with non-densified wood.
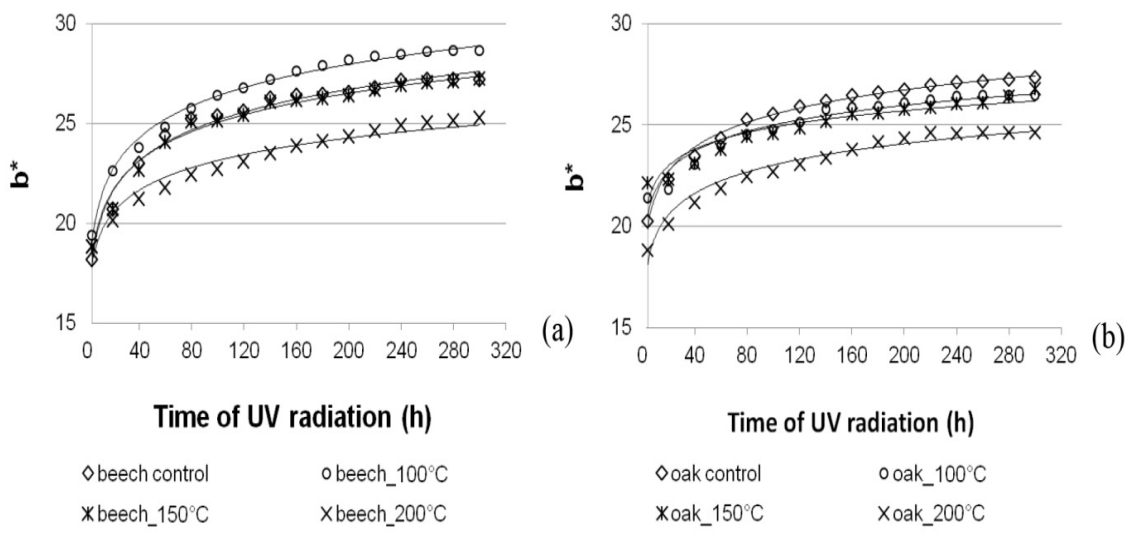

Figure 4: Change in $b^{*}$ parameter of beech (a) and oak (b) wood colour under UV radiation exposure.

Beech wood densified at a higher temperature was less susceptible to a change in the value of $b^{*}$ under the influence of light irradiation. The greatest changes in the value of $b^{*}$ under the influence of light irradiation ( $50 \%$ increase) were observed for non-densified beech wood. After $300 \mathrm{~h}$ of light irradiation, the value of $\mathrm{b}^{*}$ for beech wood densified at temperatures of $100^{\circ} \mathrm{C}, 150^{\circ} \mathrm{C}$ and $200^{\circ} \mathrm{C}$ was, respectively, $48 \%, 45 \%$ and $34 \%$ higher than before light irradiation. No clear correlation was found, however, between the influence of light irradiation and the value of $b^{*}$ for densified oak wood. After $300 \mathrm{~h}$ of light irradiation, the value of $b^{*}$ for den- 
sified oak wood was from $21 \%$ to $31 \%$ higher than before light irradiation. The values of $b^{*}$ describe a trend in the change in the colour of beech and oak wood towards yellow, caused by an increased colour saturation (Figure 8). The photochemistry of structural wood components should be seen as a cause of the change in the tonality of the wood colour to yellow. The factors accountable for wood becoming yellow include primarily lignin and its derivatives, i.e. quinones and stilbenes (Nimz 1973, Hon and Glasser 1979, Yazaki et al. 1994). Persze and Tolvaj (2012) also noted that lignin derivatives are accountable mainly for the process of wood yellowing. Chromophore groups in wood can be found primarily in lignin, extractives and their derivatives. As the temperature of treatment rises, the amount of hemicelluloses that undergo degradation increases and, consequently, the lignin content in wood and the susceptibility of wood to a change in colour towards yellow also increase. Yellowing is the main change in the colour of wood being an effect of lignin photodegradation (Hill 2006, Huang et al. 2012, Persze and Tolvaj 2012).

When analysing the changes in the wood colour occurring as a result of thermo-mechanical modification, it should be concluded that the higher the temperature of modification, the greater was the change in the colour of beech and oak wood. As a result of densification, irrespective of the temperature of modification, the $\Delta \mathrm{E}$ value of oak wood was twice as great as the $\Delta \mathrm{E}$ of beech wood. Bekhta et al. (2014a) obtained the highest values of $\Delta \mathrm{E}$ also at a modification temperature of $200^{\circ} \mathrm{C}$. Nevertheless, in the case of modifying beech at a temperature of $200^{\circ} \mathrm{C}$ they obtained significantly higher $\Delta \mathrm{E}$ values. The reason for this may be another modification process formula. The wood densification process was longer (240 s), but no prior heating was applied.
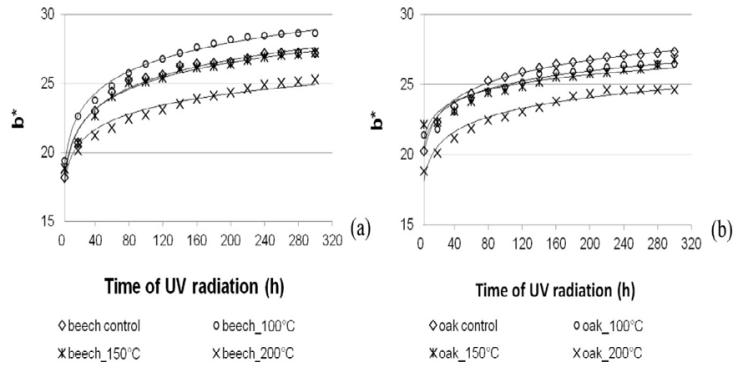

Figure 5: Total colour difference $(\Delta \mathrm{E})$ of beech (a) and oak (b) wood.

The higher the temperature of thermo-mechanical treatment, the smaller were the changes in beech and oak under the influence of ultraviolet radiation. The changes in the colour of the oak wood modified at temperatures of $100^{\circ} \mathrm{C}$ and $150^{\circ} \mathrm{C}$ under the influence of light irradiation were comparable (Figure 5). The dynamics of the changes in the wood colour under the influence of ultraviolet radiation were greater for beech wood than for oak wood. The greatest changes in the colour of beech and oak wood occurred after $20 \mathrm{~h}$ of light irradiation. Changes in colour in $20 \mathrm{~h}$ accounted for about $30 \%$ of the total colour change in non-densified beech wood and beech wood densified at temperatures of $100^{\circ} \mathrm{C}$ and $150^{\circ} \mathrm{C}$. Whereas changes in colour in $20 \mathrm{~h}$ accounted for about $40 \%$ of the total colour change in beech wood densified at a temperature of $200^{\circ} \mathrm{C}$. It was found that changes in colour in $20 \mathrm{~h}$ accounted for about $50 \%$ of the total colour change in non-densified oak wood and oak wood densified at temperatures of $100^{\circ} \mathrm{C}$ and $150^{\circ} \mathrm{C}$. Whereas in the case of the oak wood densified at a temperature of $200^{\circ} \mathrm{C}$, the changes amounted to $70 \%$. Tolvaj and Mitsui $(2010)$ noted that the differences in wood colour under the influence of light irradiation are due to differences in extractive content. Ultraviolet radiation causes degradation of extractives and then the quick oxidation of degradation products, leading to a sudden drop in lightness. The modified chromophores act as a form of an energy trap, which slows down the process of photodegradation of the main wood components. That is why the change in lightness in the case of oak is slower than in the case of beech wood. These correlations have been confirmed by the studies conducted. The differences between the colour determined after $20 \mathrm{~h}$ and $300 \mathrm{~h}$ of light irradiation of beech wood (non-densified and densified at temperatures of $100^{\circ} \mathrm{C}$ and $150^{\circ} \mathrm{C}$ ) were double as compared with the corresponding values for oak wood. In the case of beech wood densified at $200^{\circ} \mathrm{C}$, on the other hand, these differences were 300-times greater than in the case of oak wood. The colour of oak wood modified at a temperature of $200^{\circ} \mathrm{C}$ did not change significantly in $300 \mathrm{~h}$ of light irradiation. On this basis it can be concluded that wood modified thermo-mechanically at $200^{\circ} \mathrm{C}$ contains extractives and the chromophore products of hemicelluloses which are stable during light irradiation. This conclusion is confirmed by the results of the studies conducted. Tolvaj et al. (2014) found similar correlations for thermally modified and light irradiated black locust, poplar, spruce and larch wood. Pandey 2005a, Pandey 2005b studied photo-discoloration and photo-degradation of wood. Wood samples without extractives were characterised by a moderate change in the wood colour in a 
longer light irradiation time. The effects of the decomposition of lignin and extractives include also absorption changes in the whole visible wavelength region (Pastore et al. 2004, Pandey 2005b, Pandey and Vuorinen 2008, Chang et al. 2010).
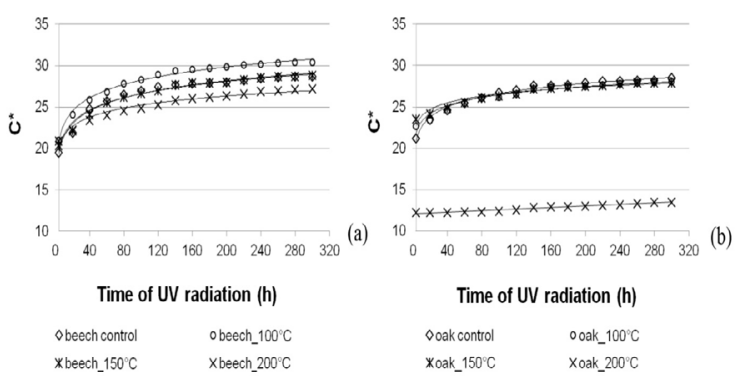

Figure 6: Change in $C^{*}$ parameter of beech (a) and oak (b) wood colour under UV radiation exposure.

The value of $C^{*}$ for non-densified beech and oak wood was respectively $19,49( \pm 0,44)$ and $21,20( \pm 0,48)$. After thermo-mechanical treatment, the value of $\mathrm{C}^{*}$ for beech wood did not change significantly $(\mathrm{p}>0,05)$ and was ca. 20 (Figure 6). The value of $\mathrm{C}^{*}$ for oak wood after thermo-mechanical treatment ranged from ca. 12 (for oak modified at a temperature of $200^{\circ} \mathrm{C}$ ) to ca. 24 (for oak modified at temperatures of $100^{\circ} \mathrm{C}$ and $150^{\circ} \mathrm{C}$ ). Greater dynamics of changes in $\mathrm{C}^{*}$ under the influence of light irradiation were found in beech wood. An increase in $\mathrm{C}^{*}$ after $300 \mathrm{~h}$ of light irradiation ranged from ca. $30 \%$ to $47 \%$. Whereas in the case of oak wood, an increase in the value of $\mathrm{C}^{*}$ ranging from $10 \%$ to $35 \%$ was found after $300 \mathrm{~h}$ of light irradiation. The lower the temperature of modification, the least susceptible beech and oak wood was to a change in the value of $\mathrm{C}^{*}$ under the influence of light irradiation.
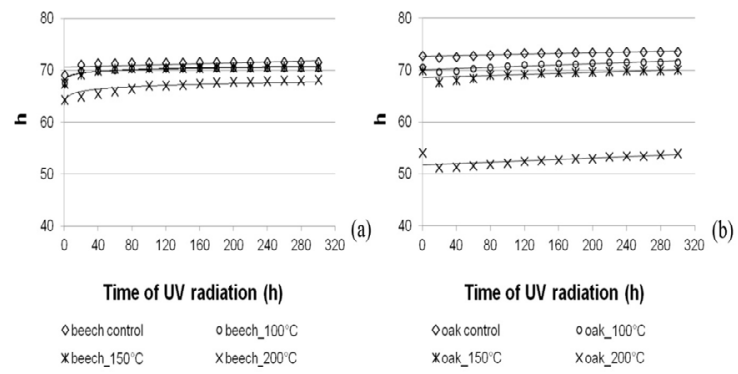

Figure 7: Change in h parameter of beech (a) and oak (b) wood colour under UV radiation exposure.

The non-densified beech and oak wood had similar values of $\mathrm{h}$ (ca. 70). After thermo-mechanical treatment, the value of $\mathrm{h}$ for beech wood and oak wood densified at a temperature of $200^{\circ} \mathrm{C}$ changed significantly. The influence of thermo-mechanical treatment on the $\mathrm{h}$ parameter of the wood colour has been confirmed in literature. Bekhta et al. (2014a) stated that the h values decreased with rising temperature for pine, beech, alder and birch veneer. After $300 \mathrm{~h}$ of light irradiation of non-densified and densified beech wood, only a $4 \%$ increase in the value of $h$ was recorded as compared with wood before light irradiation. The differences were statistically significant $(p<0,05)$. Light irradiation did not cause significant changes in the value of $h$ of non-densified and densified oak wood (Figure 7).

The equations showing the correlations between the wood colour parameters and the values of the coefficient of determination $\mathrm{R}^{2}$ were shown in Table 2. The high values of $\mathrm{R}^{2}$, close to " 1 ", indicate the usefulness of the regression equation for anticipating the value of the dependent variable $\mathrm{L}^{*}, \mathrm{a}^{*}, \mathrm{~b}^{*}, \mathrm{C}^{*}, \mathrm{~h}$ and $\Delta \mathrm{E}$ using the independent variable $t$, which is the wood light irradiation time. Regression equations of colour parameters for beech and oak wood densified throughout the range of temperatures and light irradiated is presented in Table 3. 
Table 2: Equations of curves describing the relations between $L^{*}, a^{*}, b^{*}, C^{*}, h, \Delta E$ and the time ( $\left.t\right)$ of $U V$ exposure ( $\mathrm{a}$ - directional factor, $\mathrm{b}$ - absolute term) and $\mathrm{R}^{2}$ - coefficient of determination).

\begin{tabular}{|c|c|c|c|c|c|}
\hline \multirow{2}{*}{$\begin{array}{c}\text { Wood } \\
\text { species }\end{array}$} & \multirow{2}{*}{$\begin{array}{c}\text { Temperature } \\
\text { of densification } \\
\left({ }^{\circ} \mathrm{C}\right)\end{array}$} & \multicolumn{4}{|c|}{ Parameters } \\
\hline & & $a^{*}=a \ln (t)+b$ & $\mathrm{R}^{2}$ & $\mathrm{~b}^{*}=\mathrm{a} \ln (\mathrm{t})+\mathrm{b}$ & $\mathrm{R}^{2}$ \\
\hline \multirow{4}{*}{ Becch } & control & $a^{*}=0,61 \ln (t)+5,65$ & 0,98 & $\mathrm{~b}^{*}=2,28 \ln (\mathrm{t})+14,61$ & 0,96 \\
\hline & 100 & $a^{*}=0,75 \ln (t)+6,01$ & 0,99 & $\mathrm{~b}^{*}=2,42 \ln (\mathrm{t})+15,17$ & 0,99 \\
\hline & 150 & $a^{*}=0,63 \ln (t)+6,02$ & 0,98 & $\mathrm{~b}^{*}=2,32 \ln (\mathrm{t})+14,28$ & 0,97 \\
\hline & 200 & $a^{*}=0,28 \ln (t)+8,54$ & 0,97 & $\mathrm{~b}^{*}=1,99 \ln (\mathrm{t})+13,80$ & 0,99 \\
\hline \multirow{4}{*}{ Oak } & control & $a^{*}=0,32 \ln (t)+6,27$ & 0,99 & $\mathbf{b}^{*}=1,89 \ln (\mathrm{t})+16,73$ & 0,99 \\
\hline & 100 & $a^{*}=0,21 \ln (t)+7,70$ & 0,97 & $\mathbf{b}^{*}=1,78 \ln (\mathrm{t})+16,64$ & 0,99 \\
\hline & 150 & $a^{*}=0,15 \ln (t)+8,76$ & 0,97 & $\mathrm{~b}^{*}=1,60 \ln (\mathrm{t})+17,35$ & 0,99 \\
\hline & 200 & $a^{*}=-0,07 \ln (t)+7,83$ & 0,92 & $\mathrm{~b}^{*}=1,81 \ln (\mathrm{t})+14,54$ & 0,99 \\
\hline \multirow{5}{*}{ Becch } & & $\mathrm{L}^{*}=\mathrm{at}+\mathrm{b}$ & $\mathrm{R}^{2}$ & $\Delta \mathrm{E}=\mathrm{a} \ln (\mathrm{t})-\mathrm{b}$ & $\mathrm{R}^{2}$ \\
\hline & control & $\mathrm{L}^{*}=-0,009 \mathrm{l} \mathrm{t}+70,03$ & 0,87 & $\Delta \mathrm{E}=2,66 \ln (\mathrm{t})-4,27$ & 0,98 \\
\hline & 100 & $L^{*}=-0,0068 t+66,95$ & 0,89 & $\Delta \mathrm{E}=2,77 \ln (\mathrm{t})-4,81$ & 0,98 \\
\hline & 150 & $L^{*}=-0,0059 t+66,85$ & 0,83 & $\Delta \mathrm{E}=2,44 \ln (\mathrm{t})-4,11$ & 0,99 \\
\hline & 200 & $\mathrm{~L}^{*}=0,0033 \mathrm{t}+56,19$ & 0,99 & $\Delta \mathrm{E}=1,59 \ln (\mathrm{t})-2,44$ & 0,98 \\
\hline \multirow{5}{*}{ Oak } & control & $L^{*}=-0,0045 t+63,39$ & 0,95 & $\Delta \mathrm{E}=1,73 \ln (\mathrm{t})-1,19$ & 0,99 \\
\hline & 100 & $\mathrm{~L}^{*}=-0,002 \mathrm{lt}+58,24$ & 0,96 & $\Delta \mathrm{E}=1,25 \ln (\mathrm{t})-0,86$ & 0,99 \\
\hline & 150 & $\mathrm{~L}^{*}=-0,0010 \mathrm{t}+56,86$ & 0,95 & $\Delta \mathrm{E}=0,85 \ln (\mathrm{t})+0,92$ & 0,98 \\
\hline & 200 & $L^{*}=0,0034 t+34,88$ & 0,92 & $\Delta \mathrm{E}=\mathrm{at}+\mathrm{b}$ & \\
\hline & & & & $\Delta \mathrm{E}=-0,0017 \mathrm{t}+1,60$ & 0,82 \\
\hline \multirow{5}{*}{ Becch } & & $\mathrm{C}^{*}=\mathrm{aln}(\mathrm{t})+\mathrm{b}$ & $\mathrm{R}^{2}$ & $\mathrm{~h}=\mathrm{a} \ln (\mathrm{t})+\mathrm{b}$ & $\mathrm{R}^{2}$ \\
\hline & control & $\mathrm{C}^{*}=2,30 \ln (\mathrm{t})+16,01$ & 0,95 & $\mathrm{~h}=0,21 \ln (\mathrm{t})+70,44$ & 0,97 \\
\hline & 100 & $C^{*}=2,39 \ln (t)+17,19$ & 0,99 & $\mathrm{~h}=0,27 \ln (\mathrm{t})+69,01$ & 0,88 \\
\hline & 150 & $\mathrm{C}^{*}=2,42 \ln (\mathrm{t})+15,34$ & 0,98 & $\mathrm{~h}=0,46 \ln (\mathrm{t})+68,13$ & 0,83 \\
\hline & 200 & $\mathrm{C}^{*}=1,91 \ln (\mathrm{t})+16,32$ & 0,99 & $\mathrm{~h}=1,30 \ln (\mathrm{t})+60,82$ & 0,98 \\
\hline \multirow{5}{*}{ Oak } & & & & $\mathrm{h}=\mathrm{at}+\mathrm{b}$ & $\mathrm{R}^{2}$ \\
\hline & control & $\mathrm{C}^{*}=1,88 \ln (\mathrm{t})+17,89$ & 0,99 & $\mathrm{~h}=0,0038 \mathrm{t}+72,51$ & 0,81 \\
\hline & 100 & $\mathrm{C}^{*}=1,76 \ln (\mathrm{t})+18,22$ & 0,99 & $\mathrm{~h}=0,0065 \mathrm{t}+69,51$ & 0,86 \\
\hline & 150 & $\mathrm{C}^{*}=1,49 \ln (\mathrm{t})+19,57$ & 0,99 & $\mathrm{~h}=0,0074 \mathrm{t}+68,09$ & 0,86 \\
\hline & 200 & $C^{*}=0,005 \ln (t)+12,05$ & 0,97 & $\mathrm{~h}=0,0098 \mathrm{t}+51,06$ & 0,99 \\
\hline
\end{tabular}

Table 3: Regression equations of colour parameters for beech and oak wood samples densified at all investigated ranges of temperature and light irradiated.

\begin{tabular}{|c|c|c|c|}
\hline \multicolumn{4}{|c|}{ Wood species } \\
\hline \multicolumn{2}{|l|}{ Becch } & \multicolumn{2}{|l|}{ Oak } \\
\hline Function & $\mathbf{R}^{2}$ & Function & $\mathbf{R}^{2}$ \\
\hline$a^{*}=-0,07 L^{*}+13,76$ & 0,25 & $\mathrm{a}^{*}=0,09 \mathrm{~L}^{*}+3,95$ & 0,55 \\
\hline $\mathrm{b}^{*}=0,27 \mathrm{~L}^{*}+8,12$ & 0,29 & $\mathrm{~b}^{*}=0,69 \mathrm{~L}^{*}-14,42$ & 0,96 \\
\hline$\Delta \mathrm{E}=0,29 \mathrm{~L}^{*}-11,10$ & 0,33 & $\Delta \mathrm{E}=0,17 \mathrm{~L}^{*}-4,70$ & 0,81 \\
\hline $\mathrm{C}^{*}=0,23 \mathrm{~L}^{*}+12,59$ & 0,22 & $C^{*}=0,66 L^{*}-10,82$ & 0,95 \\
\hline$C^{*}=1,73 \mathrm{a}^{*}+10,56$ & 0,22 & $C^{*}=4,61 a^{*}-17,14$ & 0,71 \\
\hline $\mathrm{C}^{*}=0,97 \mathrm{~b}^{*}+2,57$ & 0,99 & $\mathrm{C}^{*}=0,95 \mathrm{~b}^{*}+2,78$ & 0,99 \\
\hline$h=0,36 L^{*}+46,88$ & 0,83 & $\mathrm{~h}=0,83 \mathrm{~L}^{*}+22,62$ & 0,96 \\
\hline$h=-0,94 a^{*}+78,25$ & 0,10 & $\mathrm{~h}=5,58 \mathrm{a}^{*}+16,72$ & 0,66 \\
\hline $\mathrm{h}=0,58 \mathrm{~b}^{*}+54,66$ & 0,56 & $\mathrm{~h}=1,19 \mathrm{~b}^{*}+40,23$ & 0,98 \\
\hline
\end{tabular}
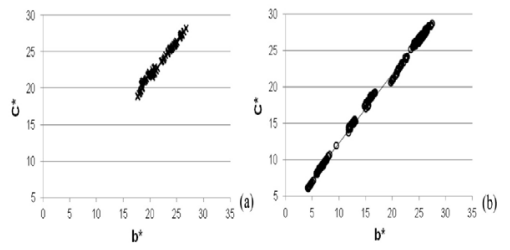

Figure 8: Correlation between yellow-blue chromatic coordinates $\left(b^{*}\right)$ and saturation $\left(C^{*}\right)$ for beech (a) and oak (b) wood samples densified at all investigated ranges of temperature and light irradiated.

The correlations among the colour parameters of the beech wood were not very pronounced. The $\mathrm{R}^{2}$ values show that a change in colour parameters is much more pronounced for oak than beech wood. The best linear correlation was found between $\mathrm{C}^{*}$ and $\mathrm{b}^{*}$ for beech as well as oak wood $\left(\mathrm{R}^{2}=0,99\right)$. This correlation shows significant changes in the value of $\mathrm{b}^{*}$ as a result of changes in $\mathrm{C}^{*}$ under the influence of the light irradiation of wood (Figure 8). Similar correlations were found by Bekhta et al. (2014b). A good linear correlation was found between $h$ and $L^{*}\left(R^{2}=0,83\right.$ for beech, $R^{2}=0,96$ for oak). Tolvaj and Mitsui (2010) found a good linear correlation between hue angle and lightness of light irradiated wood (the coefficients of determination are between 0,70 and 0,96 ). On that basis the authors concluded that the measurement of wood lightness was sufficient for estimating colour changes during photodegradation of wood. A poor linear correlation was found between $h$ and $b^{*}\left(R^{2}=0,56\right)$. In the case of oak wood, a poor linear correlation was found only between $a^{*}$ and $L^{*}$ as well as between $h$ and $a^{*}$ (the values of $\mathrm{R}^{2}$ were 0,55 and 0,66 respectively).

\section{CONCLUSIONS}

It has been found that thermo-mechanical treatment had a significant effect on a change in the colour of beech and oak wood. The higher the temperature of modification, the greater was the change in the colour of beech and oak wood. As a result of densification, irrespective of the temperature of modification, the total change in the colour of oak wood was twice as great as the total change in the colour of beech wood. The temperature of thermo-mechanical treatment had a significant influence on all the wood colour parameters, both immediately after the modification and after $300 \mathrm{~h}$ of light irradiation. The temperature of treatment 
showed the greatest influence on $\mathrm{L}^{*}$ and $\mathrm{h}$ (influence at the level of 54-60\%), and the least significant on $\mathrm{a}^{*}$ (at the level of 15-31\%). Beech and oak wood densified at a higher temperature was less susceptible to a change in $\mathrm{L}^{*}, \mathrm{a}^{*}$ and $\mathrm{b}^{*}$ under the influence of light irradiation. The greater the temperature of thermo-mechanical modification, the smaller was the $\Delta \mathrm{E}$ value for beech and oak wood under the influence of ultraviolet radiation. The changes in the colour of oak wood in time under the influence of ultraviolet radiation were smaller that the changes in beech wood. A high linear correlation has been found between $\mathrm{C}^{*}$ and $\mathrm{b}^{*}$ for the beech as well as oak wood $\left(\mathrm{R}^{2}=0,99\right)$ densified at all investigated ranges of temperature and light irradiated.

\section{REFERENCES}

Ahmed, S.A.; Morén, T.; Hagman, O.; Cloutier, A.; Fang, Ch.H.; Elustondo, D. 2013. Anatomical properties and process parameters affecting blister/blow formation in densified European aspen and downy birch sapwood boards by thermo-hygro-mechanical compression. J Mater Sci 48(24): 8571-8579. https://doi. org/10.1007/s10853-013-7679-9.

Alén, R.; Kotilainen, R.; Zaman, A. 2002. Thermochemical behavior of Norway spruce (Picea abies) at 180-225ㄷ. Wood Sci Technol 36(2): 163-171. https://doi.org/10.1007/s00226-001-0133-1.

Ayadi, N.; Lejeune, F.; Charrier, F.; Charrier, B.; Merlin, A. 2003. Color stability of heat treated wood during artificial weathering. Holz Roh Werkst 61(3): 221-226. https://doi.org/10.1007/s00107-003-0389-2.

Bekhta, P.; Niemz, P. 2003. Effect of high temperature on the change in color, dimensional stability and mechanical properties of spruce wood. Holzforschung 57(5): 539-546. https://doi.org/10.1515/HF.2003.080.

Bekhta, P.; Proszyk, S.; Krystofiak, T. 2014a. Colour in short term thermo-mechanically densified veneer of various wood species. Eur J Wood and Wood Prod 72(6): 785-797. https://doi.org/10.1007/s00107014-0837-1.

Bekhta, P.; Proszyk, S.; Lis, B.; Krystofiak, T. 2014b. Gloss of thermally densified alder (Alnus glutinosa Goertn.), beech (Fagus sylvatica L.), birch (Betula verrucosa Ehrh.), and pine (Pinus sylvestris L.) wood veneers. Eur J Wood and Wood Prod 72(6): 799-808. https://doi.org/10.1007/s00107-014-0843-3.

Bekhta, P.; Krystofiak, T. 2016. The influence of short-term thermo-mechanical densification on the surface wettability of wood veneers. Maderas-Cienc Tecnol 18(1): 79-90. https://doi.org/10.4067/S0718221X2016005000008

Belt, T.; Rautkari, L.; Laine, K.; Hill, C.A.S. 2013. Cupping behaviour of surface densified Scots pine wood: The effect of process parameters and correlation with density profile characteristics. J Mater Sci 48(18): 6426-6430. https://doi.org/10.1007/s10853-013-7443-1. https://doi.org/10.1007/s10853-013-7443-1.

Blomberg, J.; Persson, B.; Blomberg, A. 2005. Effects of semi-isostatic densification of wood on the variation in strength properties with density. Wood Sci Technol 39(5): 339-350. https://doi.org/10.1007/s00226005-0290-8.

Brischke, C.H.; Welzbacher, CH.R.; Brandt, K.; Rapp, A.O. 2007. Quality control of thermally modified timber: Interrelationship between heat treatment intensities and CIE L*a*b* color data on homogenized wood samples. Holzforschung 61(1): 19-22. https://doi.org/10.1515/HF.2007.004.

Chang, T.C.; Chang, H.T.; Wu, C.L.; Chang, S.T. 2010. Influences of extractives on the photodegradation of wood. Polym Degrad Stabil 95: 516-521. https://doi.org/10.1016/j.polymdegradstab.2009.12.024.

Cruz, N.; Bustos, C.A.; Aguayo, M.G.; Cloutier, A.; Castillo, R. 2018. Impact of the chemical composition of Pinus radiata wood on its physical and mechanical properties following thermo-hygromechanical densification. BioResources 13(2): 2268-2282. https://doi.org/10.15376/biores.13.2.2268-2282.

Diouf, P.N.; Stevanovic, T.; Cloutier, A.; Fang, Ch.H.; Blanchet, P.; Koubaa, A.; Mariotti, N. 2011. Effects of thermo-hygro-mechanical densification on the surface characteristics of trembling aspen and hybrid poplar wood veneers. Appl Surf Sci 257: 3558-3564. https://doi.org/10.1016/j.apsusc.2010.11.074.

Dogu, D.; Tirak, K.; Candan, Z.; Unsal, O. 2010. Anatomical investigation of thermally compressed wood panels. BioResources 5(4): 2640-2663. 
Esteves, B.; Marques, V.; Domingos, A.; Pereira, H. 2013. Chemical changes of heat treated pine and eucalypt wood monitored by FTIR. Maderas-Cienc Tecnol 15(2): 245-258. https://doi.org/10.4067/S0718$221 X 2013005000020$.

Fang, Ch.H.; Mariotti, N.; Cloutier, A.; Koubaa, A.; Blanchet, P. 2011. Densification of wood veneers by compression combined with heat and steam. Eur J Wood and Wood Prod 70: 155-163. https://doi. org/10.1007/s00107-011-0524-4.

Fang, Ch.H.; Cloutier, A.; Jiang, Z.H.; He, J.Z.; Fei, B.H. 2019. Improvement of wood densification process via enhancing steam diffusion, distribution, and evaporation. BioResources 14(2): 3278-3288. https:// doi.org/10.15376/biores.14.2.3278-3288.

Gašparik, M.; Gaff, M.; Šafařiková, L.; Vallejo, C.R.; Svoboda, T. 2016. Impact bending strength and Brinell hardness of densified hardwoods. BioResources 11(4): 8638-8652. https://doi.org/10.15376/ biores.11.4.8638-8652.

Gierlinger, N.; Jacques, D.; Grabner, M.; Wimmer, R.; Schwanninger, M.; Rozenberg, P.; Pâques, L.E. 2004. Colour of larch heartwood and relationships to extractives and brown-rot decay resistance. Trees 18(1): 102-108. https://doi.org/10.1007/s00468-003-0290-y.

González-Peña, M.M.; Hale, M.D.C. 2009. Colour in thermally modified wood of beech, Norway spruce and Scots pine. Part 2: Property predictions from colour changes. Holzforschung 63(4): 394-401. https://doi. org/10.1515/HF.2009.077.

Hill, C.A.S. 2006. Wood Modification: Chemical, Thermal and Other Processes. John Wiley \& Sons, Ltd: Chichester, UK.

Hon, D.N.S.; Glasser, W. 1979. On possible chromophoric structures in wood and pulps. Polym Plast Technol Eng 12(2): 159-179. https://doi.org/10.1080/03602557908067670.

Huang, X.; Kocaefe, D.; Kocaefe, Y.; Boluk, Y.; Pichette, A. 2012. A spectrocolorimetric and chemical study on color modification of heat-treated wood during artificial weathering. Appl Surf Sci 258(14): 53605369. https://doi.org/10.1016/j.apsusc.2012.02.005.

International Organization for Standardization. ISO. 1984. Paints and varnishes - Colorimetry - Part 3: Calculation of colour differences. ISO 7724-3. 1984. International Organization for Standardization: Geneva, Switzerland.

International Organization for Standardization. ISO. 2014. Physical and mechanical properties of wood - Test methods for small clear wood specimens - Part 1: Determination of moisture content for physical and mechanical tests. ISO 13061-1. 2014. International Organization for Standardization: Geneva, Switzerland.

International Organization for Standardization. ISO. 2014. Physical and mechanical properties of wood - Test methods for small clear wood specimens - Part 2: Determination of density for physical and mechanical tests. ISO 13061-2. 2014. International Organization for Standardization: Geneva, Switzerland.

İmirzi, H.Ö.; Ülker, O.; Burdurlu, R. 2014. Effect of densification temperature and some surfacing techniques on the surface roughness of densified scots pine (Pinus sylvestris L.). BioResources 9(1): 191-209.

Johansson, D.; Morén, T. 2006. The potential of colour measurement for strength prediction of thermally treated wood. Holz Roh Werkst 64(2): 104-110. https://doi.org/10.1007/s00107-005-0082-8.

Jiang, J.; Lu, J.; Huang, R.; Li, X. 2009. Effects of time and temperature on the viscoelastic properties of Chinese fir wood. Dry Technol 27(11): 1229-1234. https://doi.org/10.1080/07373930903266726.

Kutnar, A.; Kamke, F.A.; Sernek, M. 2009. Density profile and morphology of viscoelastic thermal compressed wood. Wood Sci Technol 43(1): 57-68. https://doi.org/10.1007/s00226-008-0198-1.

Kutnar, A.; Kamke, F.A. 2012. Influence of temperature and steam environment on set recovery of compressive deformation of wood. Wood Sci Technol 46(5): 953-964. https://doi.org/10.1007/s00226-011-0456-5. 
Laine, K.; Rautkari, L.; Hughes, M. 2013a. The effect of process parameters on the hardness of surface densified Scots pine solid wood. Eur J Wood and Wood Prod 71(1): 13-16. https://doi.org/10.1007/s00107012-0649-0.

Laine, K.; Rautkari, L.; Hughes, M.; Kutnar, A. 2013b. Reducing the set-recovery of surface densified solid Scots pine wood by hydrothermal post-treatment. Eur J Wood and Wood Prod 71(1): 17-23. https://doi. org/10.1007/s00107-012-0647-2.

Laine, K.; Segerholm, K.; Wålinder, M.; Rautkari, L.; Ormondroyd, G.; Hughes, M.; Jones, D. 2014. Micromorphological studies of surface densified wood. J Mater Sci 49(5): 2027-2034. https://doi.org/10.1007/ s10853-013-7890-8.

Laine, K.; Segerholm, K.; Wålinder, M.; Rautkari, L.; Hughes, M. 2016. Wood densification and thermal modification: Hardness, set-recovery and micromorphology. Wood Sci Technol 50(5): 883-894. https://doi. org/10.1007/s00226-016-0835-z.

Laskowska, A.; Marchwicka, M.; Boruszewski, P.; Wyszyńska, J. 2018. Chemical composition and selected physical properties of oak wood (Quercus robur L.) modified by cyclic thermo-mechanical treatment. BioResources 13(4): 9005-9019. https://doi.org/10.15376/biores.13.4.9005-9019.

Laskowska, A.; Sobczak, J.W. 2018. Surface chemical composition and roughness as factors affecting the wettability of thermo-mechanically modified oak (Quercus robur L.). Holzforschung 72(11): 993-1000. https://doi.org/10.1515/hf-2018-0022.

Miller, S.A.; Hamilton, S.L.; Wester, U.G.; Cyr, W.H. 1998. An analysis of UVA emissions from sunlamps and the potential importance for melanoma. Photochem Photobiol 68(1): 63-70.

Mitsui, K.; Takada, H.; Sugiyama, M.; Hasegawa, R. 2001. Changes in the properties of light-irradiated wood with heat treatment. Part 1. Effect of treatment conditions on the change in color. Holzforschung 55: 601605. https://doi.org/10.1515/HF.2001.098.

Navi, P.; Girardet, F. 2000. Effects of thermo-hydro-mechanical treatment on the structure and properties of wood. Holzforschung 54(3): 287-293. https://doi.org/10.1515/HF.2000.048.

Nimz, H.H. 1973. Chemistry of potential chromophoric groups in beech lignin. Tappi J 56(5): 124-126.

Pandey, K.K. 2005a. A note on the influence of extractives on the photo-discoloration and photo-degradation of wood. Polym Degrad Stabil 87(2): 375-379. https://doi.org/10.1016/j.polymdegradstab.2004.09.007.

Pandey, K.K. 2005b. Study of the effect of photo-irradiation on the surface chemistry of wood. Polym Degrad Stabil 90(1): 9-20. https://doi.org/10.1016/j.polymdegradstab.2005.02.009.

Pandey, K.K.; Vuorinen, T. 2008. Comparative study of photodegradation of wood by a UV laser and a xenon light source. Polym Degrad Stabil 93(12): 2138-2146. https://doi.org/10.1016/j.polymdegradstab.2008.08.013.

Pastore, T.C.M.; Santos, K.O.; Rubim, J.C. 2004. A spectrocolorimetric study on the effect of ultraviolet irradiation of four tropical hardwoods. Bioresource Technol 93(1): 37-42. https://doi.org/10.1016/j. biortech.2003.10.035.

Pařil, P.; Brabec, M.; Maňák, O.; Rousek, R.; Rademacher, P.; Čermák, P.; Dejmal, A. 2014. Comparison of selected physical and mechanical properties of densified beech wood plasticized by ammonia and saturated steam. Eur J Wood and Wood Prod 72(5): 583-591. https://doi.org/10.1007/s00107-014-0814-8.

Pelit, H.; Sönmez, A.; Budakçi, M. 2014. Effects of ThermoWood® Process Combined with ThermoMechanical Densification on some Physical Properties of Scots Pine (Pinus sylvestris L.). BioResources 9(3): 4552-4567.

Pelit, H.; Budakçi, M.; Sönmez, A. 2016. Effects of Heat Post-Treatment on Dimensional Stability and Water Absorption Behaviours of Mechanically Densified Uludağ Fir and Black Poplar Woods. BioResources 11(2): 3215-3229. https://doi.org/10.15376/biores.11.2.3215-3229. 
Persze, L.; Tolvaj, L. 2012. Photodegradation of wood at elevated temperature: colour change. $J$ Photochem Photobiol B 108: 44-47. https://doi.org/10.1016/j.jphotobiol.2011.12.008.

Pétrissans, A.; Younsi, R.; Chaouch, M.; Gérardin, P.; Pétrissans, M. 2014. Wood thermodegradation: experimental analysis and modeling of mass loss kinetics. Maderas-Cienc Tecnol 16(2): 133-148.

Popescu, M.C.; Lisa, G.; Froidevaux, J.; Navi, P.; Popescu, C.M. 2014. Evaluation of the thermal stability and set recovery of thermo-hydro-mechanically treated lime (Tilia cordata) wood. Wood Sci Technol 48(1): 85-97. https://doi.org/10.1007/s00226-013-0588-x.

Rautkari, L.; Properzi, M.; Pichelin, F.; Hughes, M. 2009. Surface modification of wood using friction. Wood Sci Technol 43(3): 291-299. https://doi.org/10.1007/s00226-008-0227-0.

Rautkari, L.; Properzi, M.; Pichelin, F.; Hughes, M. 2010. Properties and set-recovery of surface densified Norway spruce and European beech. Wood Sci Technol 44(4): 679-691. https://doi.org/10.1007/s00226009-0291-0.

Rautkari, L.; Laine, K.; Laflin, N.; Hughes, M. 2011. Surface modification of Scots pine: the effect of process parameters on the through thickness density profile. J Mater Sci 46(14): 4780-4789. https://doi. org/10.1007/s10853-011-5388-9.

Rautkari, L.; Laine, K.; Kutnar, A.; Medved, S.; Hughes, M. 2013. Hardness and density profile of surface densified and thermally modified Scots pine in relation to degree of densification. J Mater Sci 48(6): 2370-2375. https://doi.org/10.1007/s10853-012-7019-5.

Salmén, L. 1982. Temperature and water induced softening behaviour of wood fiber based materials. The Royal Institute of Technology: Stockholm, Sweden.

Schrepfer, V.; Schweingruber, F.H. 1998. Anatomical structures in reshaped press-dried wood. Holzforschung 52(6): 615-622. https://doi.org/10.1515/hfsg.1998.52.6.615.

Tolvaj, L.; Mitsui, K. 2010. Correlation between hue angle and lightness of light irradiated wood. Polym Degrad Stabil 95: 638-642. https://doi.org/10.1016/j.polymdegradstab.2009.12.004.

Tolvaj, L.; Nemeth, R.; Pasztory, Z.; Bejo, L.; Takats, P. 2014. Colour Stability of Thermally Modified Wood during Short Term Photodegradation. BioResources 9(4): 6644-6651.

Tu, D.; Su, X.; Zhang, T.; Fan, W.; Zhou, Q. 2014. Thermo-mechanical densification of Populus tomentosa var. tomentosa with low moisture content. BioResources 9(3): 3846-3856.

Ulker, O.; Imirzi, Ö.; Burdurlu, E. 2012. The effect of densification temperature on some physical and mechanical properties of Scots pine (Pinus sylvestris L.). BioResources 7(4): 5581-5592.

Wagenführ, R. 2007. Holzatlas. Fachbuchverlag Leipzig im Carl Hanser Verlag: München, Germany.

Welzbacher, C.R.; Wehsener, J.; Rapp, A.O.; Haller, P. 2008. Thermo-mechanical densification combined with thermal modification of Norway spruce (Picea abies Karst) in industrial scale - Dimensional stability and durability aspects. Holz Roh Werkst 66: 39-49. https://doi.org/10.1007/s00107-007-0198-0.

Xu, X.; Tang, Z. 2012. Vertical compression rate profile and dimensional stability of surface-densified plantation poplar wood. Lignocellulose 1(1): 45-54.

Yazaki, Y.; Collins, P.J.; Mccombe, B. 1994. Variations in hot water extractives content and density of commercial wood veneers from blackbutt (Eucalyptus pilularis). Holzforschung 48 (s1): 107-111. https://doi. org/10.1515/hfsg.1994.48.s1.107.

Zhan, J.F.; Avramidis, S. 2016. Needle fir wood modified by surface densification and thermal post-treatment: Hygroscopicity and swelling behavior. Eur J Wood Prod 74 (1): 49-56. https://doi.org/10.1007/s00107015-0969-y. 